\title{
A Glycosidic Isoflavonoid from Viola hondoensis W. BECKER et H. BOISSIEU (Violaceae), and Its Effect on the Expression of Matrix Metalloproteinase- 1 Caused by Ultraviolet Irradiation in Cultured Human Skin Fibroblasts
}

\author{
Hyung In Moon, ${ }^{*, a}$ Joongku LeE, $^{b}$ Ok Pyo ZeE, ${ }^{c}$ and Jin Ho ChunG ${ }^{*, a}$ \\ ${ }^{a}$ Department of Dermatology, Seoul National University College of Medicine, and Clinical research Institute, Seoul \\ National University Hospital; Seoul, 110-744, Korea: ${ }^{b}$ Korea Research Institute of Bioscience and Biotechnology; \\ Daejeon, 305-333, Korea: and ${ }^{C}$ College of Pharmacy, Sung Kyun Kwan University; Suwon, 440-746, Korea. \\ Received February 23, 2005; accepted March 22, 2005
}

\begin{abstract}
Isolation of the ethyl acetate soluble fraction from aerial parts of Viola hondoensis W. BECKER et H. BOISSIEU yielded one major isoflavonoid glycoside, tectoridin-4'-O- $\beta$-D-glucoside. The structure of the compound was certainly determined by chemical analyses, as well as 1D- and 2D-NMR spectroscopy. The compound exhibited potent inhibitory activity against the expression of matrix metalloproteinase-1 caused by UV-irradiation in cultured human skin fibroblasts.
\end{abstract}

Key words Viola hondoensis; tectoridin-4'-O- $\beta$-D-glucoside; matrix metalloproteinase; human skin fibroblasts

Viola hondoensis W. BECKer et H. BoIssieu (Violaceae) is distributed in the southern part of Korea. ${ }^{1)}$ In traditional medicine, the herb has been used as an expectorant and a remedy for skin eruptions. ${ }^{2)}$ Previous pharmacological and phytochemical studies on Viola species have revealed to be a rich source of cyclotides, ${ }^{3)}$ and several flavone glycosides. ${ }^{4)}$ Antiphotoaging activity of $V$. hondoensis was also reported. ${ }^{5)}$

Matrix metalloproteinases (MMPs) are a family of zincdependent endoproteinases that play pivotal roles in the dynamic remodeling of extracellular matrix. Based on substrate preference and structural homology, MMPs are sub-classified into functional groups: collagenases, gelatinases, stromelysins, matrilysins, membrane type-MMPs (MT-MMPs) and other non-classified MMPs. ${ }^{6)}$ Naturally aged skin is smooth, pale, and finely wrinkled. In contrast, photoaged skin is coarsely wrinkled.7) With increasing age, matrix metalloproteinase (MMP) -1 levels become higher in human skin in vivo. ${ }^{8)} \mathrm{UV}$ irradiation induces the synthesis of MMP1 in fibroblasts in vitro and MMP-mediated collagen destruction accounts, in large part, for the connective tissue damage that occurs in photoaging. ${ }^{9)}$ In this paper, we report the isolation and structure determination of the constituent of $V$. hondoensis which inhibit expression of MMP-1 by UVirradiation in cultured human skin fibroblasts.

\section{MATERIAL AND METHODS}

General Experimental Procedures The melting points were determined using by Fisher Scientific melting point apparatus (Fisher Scientific) and were uncorrected. UV spectra were obtained on a Shimadzu UV/Visible Spectrophotometer. The IR spectra were measured in $\mathrm{KBr}$ pellets using an IMS 85 (Bruker). The NMR spectra were recorded on a Varian Unity Inova 500 spectrometer. The chemical shifts are expressed in parts per million (ppm) relative to TMS as the internal standard, and the coupling constants $(J)$ are given in Hertz. The HMBC and 2D-NOESY NMR spectra were obtained with the usual pulse sequences. The HR-FABMS was recorded on a JEOL JMS 700 mass spectrometer. TLC and the preparative TLC were carried out on precoated Silica gel $\mathrm{F}_{254}$ (Merck, art. 5715) and RP-18 $\mathrm{F}_{254}$ s (Merck, art. 15389) plates. Column chromatography was performed on Silica gel 60 (Merck, $40-63$ and $63-200 \mu \mathrm{m}$ ), TSK gel TOYOPEARL HW-40 (TOSOH, cat. no. 07449), and Sephadex LH-20 (Sigma, 25-100 $\mu \mathrm{m}$ ).

Plant Material The whole plants of Viola hondoensis were collected in April 2004 at Ulleung island, Korea. The botanical identification was made by one of the authors, Dr. Joongku Lee. A voucher specimen of this raw material has been deposited at the herbarium of the Seoul National University (SNU-03-10-01).

Extraction and Isolation The air-dried aerial parts $(430 \mathrm{~g})$ from $V$. hondoensis was extracted with $\mathrm{MeOH}$ at $80^{\circ} \mathrm{C}(3 \times 11$ for $4 \mathrm{~h})$. The $\mathrm{MeOH}$ extract $(53 \mathrm{~g})$, which was suspended in water and successively partitioned with $n$ hexane (22 g), $\mathrm{CHCl}_{3}(3 \mathrm{~g})$, EtOAc (7 g), and $n$-BuOH (13 g). Among these fractions, the $\mathrm{MeOH}$ extract had inhibitory effect against a MMP-1 expression; the MMP-1 expression level decreased to $84.6 \%$ at $10 \mu \mathrm{g} / \mathrm{ml}$ and $73.2 \%$ at $100 \mu \mathrm{g} / \mathrm{ml}$ compared with the control by human MMP-1 promoter luciferase assay, and the EtOAc extract had potent inhibitory effect against a MMP-1 expression; the MMP-1 expression level decreased to $72.8 \%$ at $10 \mu \mathrm{g} / \mathrm{ml}$ and $53.7 \%$ at $100 \mu \mathrm{g} / \mathrm{ml}$ compared with the control by human MMP-1 promoter luciferase assay. The EtOAC extract $(6 \mathrm{~g})$ was subjected to column chromatography on silica gel $(63-200 \mu \mathrm{m}$, $310 \mathrm{~g}, 4.5 \times 68 \mathrm{~cm})$ eluting with $n$-hexane followed by $n$ hexane-EtOAc $(20: 1,4: 1,3: 2,2: 3,1: 4,1: 20$, each 51$)$ and finally with $\mathrm{CHCl}_{3}-\mathrm{MeOH}(1: 1,2.51)$. The fractions were pooled into 6 major subfractions (E1 (1.3 g, 11), E2 (12.8 mg, 1.5 1), E3 (32.5 mg, 11), E4 (430.4 mg, 1.51$)$, E5 (103.2 mg, 1 1), E6 (2.6 g, 1.5 1)) based on their TLC profiles. Among these subfractions the MMP-1 expression level decreased to $82.6 \%$ at $1 \mu \mathrm{g} / \mathrm{ml}$ and $93.2 \%$ at $10 \mu \mathrm{g} / \mathrm{ml}$ compared with the control by subfraction E4 human MMP-1 promoter luciferase assay. The subfraction E4 (425 mg), containing major compound was purified by column chromatography on a silica gel (Merck, 40-63 $\mathrm{m}, 500 \mathrm{~g}, 2.3 \times 70 \mathrm{~cm}$, $\mathrm{CHCl}_{3} / \mathrm{MeOH} / \mathrm{Me}_{2} \mathrm{CO} / \mathrm{H}_{2} \mathrm{O}, 40: 3: 1.5: 0.3$ (21) $\rightarrow 35: 4: 1$ : 0.3 (21) $30: 3: 1: 0.1$ (61) $\rightarrow 30: 4: 2: 0.3$ (31)), and was followed with a gel filtration column (Sephadex LH-20, $25 \mathrm{~g}$, $\left.2.0 \times 69 \mathrm{~cm}, \quad \mathrm{MeOH} / \mathrm{H}_{2} \mathrm{O}, \quad 1: 1 \quad(500 \mathrm{ml}) \rightarrow 3: 2 \quad(500 \mathrm{ml})\right)$, 
Table $1 .{ }^{13} \mathrm{C}-,{ }^{1} \mathrm{H}-\mathrm{NMR}$ Data of Compound (1) in DMSO- $d_{6}(\delta \mathrm{ppm}, J$ in $500 \mathrm{MHz})$

\begin{tabular}{|c|c|c|}
\hline \multirow{2}{*}{ Position } & \multicolumn{2}{|c|}{1} \\
\hline & $\delta_{\mathrm{C}}$ & $\delta_{\mathrm{H}}$ \\
\hline \multicolumn{3}{|l|}{ Aglycone } \\
\hline 2 & $152.2(\mathrm{CH})$ & $8.51(\mathrm{~s})$ \\
\hline 3 & $121.3(\mathrm{C})$ & - \\
\hline 4 & $180.9(\mathrm{C})$ & - \\
\hline 5 & $152.3(\mathrm{C})$ & - \\
\hline 6 & $132.7(\mathrm{C})$ & - \\
\hline 7 & $156.0(\mathrm{C})$ & - \\
\hline 8 & $94.1(\mathrm{C})$ & $6.91(\mathrm{~s})$ \\
\hline 9 & $152.1(\mathrm{C})$ & - \\
\hline 10 & $106.2(\mathrm{C})$ & - \\
\hline $1^{\prime}$ & $124.2(\mathrm{C})$ & - \\
\hline $2^{\prime}, 6^{\prime}$ & $130.1(\mathrm{CH})$ & $7.53(\mathrm{~d}, 8.8,8.8)$ \\
\hline $3^{\prime}, 5^{\prime}$ & $116.2(\mathrm{CH})$ & $7.13(\mathrm{~d}, 8.9,8.9)$ \\
\hline $4^{\prime}$ & $157.1(\mathrm{C})$ & - \\
\hline \multicolumn{3}{|c|}{$\beta$-D-Glc (C-7) } \\
\hline $1^{\prime \prime}$ & $100.4(\mathrm{CH})$ & $4.94(\mathrm{~d}, 7.7)$ \\
\hline $2^{\prime \prime}$ & $73.3(\mathrm{CH})$ & $3.58(\mathrm{dd}, 7.7,8.5)^{a)}$ \\
\hline $3^{\prime \prime}$ & $75.3(\mathrm{CH})$ & $\left.3.52-3.50(\mathrm{~m})^{a}\right)$ \\
\hline $4^{\prime \prime}$ & $69.1(\mathrm{CH})$ & $3.47(\mathrm{br} \mathrm{d}, 9.0)^{a)}$ \\
\hline $5^{\prime \prime}$ & $76.2(\mathrm{CH})$ & $3.42(\mathrm{td}, 11.0,5.5)^{a}$ \\
\hline $6^{\prime \prime}$ & $60.2\left(\mathrm{CH}_{2}\right)$ & $3.88(\mathrm{~d}, 5.5)$ \\
\hline \multicolumn{3}{|c|}{$\beta$-D-Glc $\left(\mathrm{C}-4^{\prime}\right)$} \\
\hline $1^{\prime \prime \prime}$ & $100.7(\mathrm{CH})$ & $5.12(\mathrm{~d}, 7.6)$ \\
\hline $2^{\prime \prime \prime}$ & $73.7(\mathrm{CH})$ & $3.51(\mathrm{dd}, 7.6,8.3)^{a)}$ \\
\hline $3^{\prime \prime \prime}$ & $76.8(\mathrm{CH})$ & $\left.3.50-3.48(\mathrm{~m})^{a}\right)$ \\
\hline $4^{\prime \prime \prime}$ & $67.2(\mathrm{CH})$ & $3.43(\mathrm{br} \mathrm{d}, 8.7)^{a)}$ \\
\hline $5^{\prime \prime \prime}$ & $77.2(\mathrm{CH})$ & $3.41(\mathrm{td}, 11.0,5.3)^{a}$ \\
\hline $6^{\prime \prime \prime}$ & $61.0\left(\mathrm{CH}_{2}\right)$ & $3.86(\mathrm{~d}, 5.3)$ \\
\hline $\mathrm{OCH}_{3}$ & $60.8\left(\mathrm{CH}_{3}\right)$ & $3.78(\mathrm{~s})$ \\
\hline $5-\mathrm{OH}$ & & 12.89 (br) \\
\hline
\end{tabular}

a) Overlapped.

preparative TLC (RP-18 $\mathrm{F}_{254} \mathrm{~s}, 0.5 \mathrm{~mm}, \mathrm{MeOH} / \mathrm{H}_{2} \mathrm{O}, 1: 1$ ), and finally with TOYOPEARL HW- $40(40 \mathrm{~g}, 2.8 \times 70 \mathrm{~cm}$, $\left.\mathrm{MeOH} / \mathrm{H}_{2} \mathrm{O}, 1: 1(500 \mathrm{ml})\right)$ to give the compound $1(15 \mathrm{mg})$.

Tectoridin-4'- $\boldsymbol{O}$ - $\boldsymbol{\beta}$-D-glucoside White plate crystals, IR $(\mathrm{KBr}) v_{\max }\left(\mathrm{cm}^{-1}\right): 3600-3200(\mathrm{OH}), 1755(\mathrm{C}=\mathrm{O}), 1595$, 1510 (aromatic ring); UV $\lambda_{\max }(\mathrm{EtOH}) \mathrm{nm}(\log \varepsilon): 219$ (4.21), 271 (3.81) 333 (1.72); + $\mathrm{AlCl}_{3}, 276,329$ (sh); $+\mathrm{AlCl}_{3} / \mathrm{HCl}, 278,321$ (sh); + NaOAc 269, 328. FAB-MS (positive); $[\mathrm{M}+1]^{+} \mathrm{m} / z 625$ (Calc. for $\mathrm{C}_{28} \mathrm{H}_{32} \mathrm{O}_{16}$ ); HR-FABMS $m / z 625.4566$ (Calc. for $\mathrm{C}_{28} \mathrm{H}_{32} \mathrm{O}_{16}[\mathrm{M}+\mathrm{H}]^{+}, 625.4566$ ); ${ }^{1} \mathrm{H}-\left(500 \mathrm{MHz}, \mathrm{DMSO}-d_{6}\right)$, and ${ }^{13} \mathrm{C}-\left(125 \mathrm{MHz}, \mathrm{DMSO}-d_{6}\right)$ NMR spectral data are given in Table 1.

Acid Hydrolysis Compound $\mathbf{1}(10 \mathrm{mg})$ was hydrolyzed according to the method of Yook et al. ${ }^{10)}$ [GC conditions: column: OV-17 $(0.32 \mathrm{~mm} \times 30 \mathrm{~m})$, detector: FID, column temp.: $230{ }^{\circ} \mathrm{C}$, detector temp.: $270^{\circ} \mathrm{C}$, injector temp.: $270^{\circ} \mathrm{C}$, carrier gas: $\left.\mathrm{He}\left(2.2 \mathrm{~kg} / \mathrm{cm}^{2}\right)\right]$. The peak corresponding to a Dglucose was detected at $t_{\mathrm{R}} 7 \mathrm{~min} 12 \mathrm{~s}$. The standard monosaccharide was subjected to same reaction and followed by GC analysis under the same conditions.

Luciferase Assay For human MMP-1 promoter analysis, NIH3T3 cells were plated into 6-well plates at a density of $1 \times 10^{5} /$ well. The cells were transfected with human MMP-1 promoter reporter plasmid DNA. $24 \mathrm{~h}$ after incubated, the medium was changed for medium with or without 10 , $100 \mu \mathrm{g} / \mathrm{ml}$ sample, and cell lysates were collected for the luciferase assay from $24 \mathrm{~h}$ later. The luciferase activities of the cell lysates were measured according to the manufacturer's recommendations (Applied Biosystems).

Human Skin Fibroblast Cell Culture and Cell Proliferation Assay Primary cultures of human skin fibroblasts were established from human adult foreskin in Dulbecco's modified eagle medium (DMEM) supplemented with $10 \%$ fetal calf serum, $2 \mathrm{~mm}$ glutamine, and penicillin $(100 \mathrm{U} / \mathrm{ml})$, streptomycin $(100 \mu \mathrm{g} / \mathrm{ml})$ in a $37^{\circ} \mathrm{C}$ humidified incubator containing $5 \% \mathrm{CO}_{2}$. The fibroblasts were cultured until $90 \%$ confluency and then, subcultivated. Cells cultured after 5 passages were used for the experiments. Cell proliferation of human skin fibroblasts $\left(5 \times 10^{5} /\right.$ well $)$ was determined by the MTT assay. ${ }^{11)}$

UV Irradiation The UV light source was a F75/85W/UV21 fluorescent sun lamps, having an emission spectrum between $285-350 \mathrm{~nm}$ (peak at $310-315 \mathrm{~nm}$ ) as previously described. ${ }^{5)}$ A Kodacel filter (TA401/407; Kodak, Rochester, NY, U.S.A.) was mounted $2 \mathrm{~cm}$ in front of the UV tubes to remove wavelengths $<290 \mathrm{~nm}$ (UV-C). The fibroblasts were grown in $10 \mathrm{~cm}$ culture dishes (Falcon, Lincoln Park, NJ, U.S.A.) until subconfluent. Subsequently, the cells were cultured in serum-free medium for $24 \mathrm{~h}$, and the medium was replaced by $2 \mathrm{ml}$ of phosphate-buffered saline. Then the cells were exposed to UV $\left(0-100 \mathrm{~mJ} / \mathrm{cm}^{2}\right)$ light. After irradiation ( $1 \mathrm{~min} 20 \mathrm{~s})$, the cells were washed with phosphate-buffered saline, and $72 \mathrm{~h}$ cultured in the serum free media with or without compounds.

Western Blot and Statistical Analysis Supernatant extract were centrifuged at $12000 \times \boldsymbol{g}$ for $10 \mathrm{~min}$, and used for western blot analysis. A monoclonal anti-MMP-1 antibody (Oncogen, Co., Boston, MA, U.S.A.) was used as primary antibodies. Anti-mouse IgG-HRP conjugates was used as secondary antibodies. The antibody-antigen complexes were detected using the ECL system (Amersham Pharmacia Biotech; Little Chalfont, U.K.). Signal strengths were quantified using a densitometric program (TINA; Raytest Isotopenme gerate, Germany). Statistical significance was determined using the Student $t$-tests. Results are presented by means \pm S.E.M. All $p$ values quoted are two-tailed and were accepted as significant when $p$ was $\leq 0.05(n=10)$.

\section{RESULTS AND DISCUSSION}

Column chromatographic isolation of the ethyl acetate soluble fraction from aerial parts of $V$. hondoensis yielded an isoflavonoid glycoside (1) which inhibit expression of MMP1 by UV-irradiation in cultured human skin fibroblast. (Fig. 1). It has been reported that new isoflavonoid glycoside from Iris spuria L. $^{12)}$ Compound (1) was obtained as white plate crystals. The molecular formula of $\mathbf{1}$ was found to be $\mathrm{C}_{28} \mathrm{H}_{32} \mathrm{O}_{16}$ by HR-FAB-MS spectrometry $(\mathrm{m} / \mathrm{z} \quad 625.4566$ $\left.[\mathrm{M}+\mathrm{H}]^{+}\right)$. The UV spectrum of $\mathbf{1}$ exhibited absorption maxima at 219, 271 and $333 \mathrm{~nm}$, which are characteristic absorption bands of isoflavonoid, and showed bathochromic shift characteristic in positive reaction with $\mathrm{AlCl}_{3}$ reagents. A positive reaction in $\mathrm{AlCl}_{3}$ reagent same suggested the substitutions in this compound. ${ }^{13)}$ In the IR spectrum of 1 , absorbtions due to a hydroxyl $\left(3600-3200 \mathrm{~cm}^{-1}\right)$, unsaturated carbonyl $\left(1755 \mathrm{~cm}^{-1}\right)$, and aromatic ring $\left(1595,1510 \mathrm{~cm}^{-1}\right)$ were observed. On acid hydrolysis of $\mathbf{1}$, compound gave the D-glucose as the sugar component by GC analysis after diastereomeric derivatization. Spectral data for obtained the 


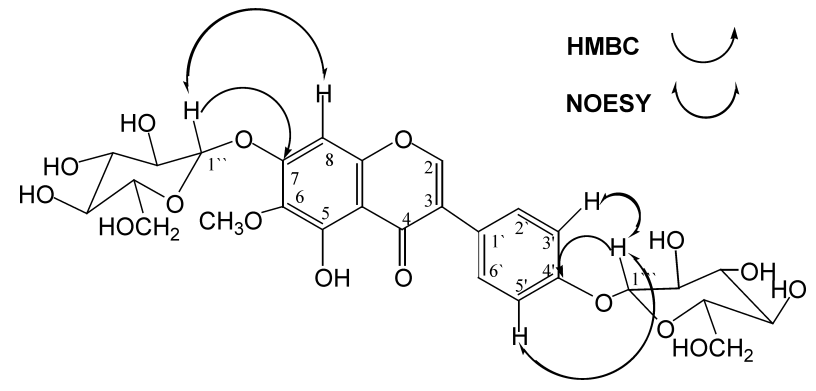

Fig. 1. Structure of Compound (1)

aglycone from 1 were identical to those of tectorigenin. ${ }^{13)}$ The ${ }^{1} \mathrm{H}-\mathrm{NMR}$ spectrum of 1 showed six aromatic protons at $\delta$ $6.91(\mathrm{H}-8), \delta 7.13\left(J=8.9 \mathrm{~Hz}, \mathrm{H}-3^{\prime}, 5^{\prime}\right), \delta 7.53(J=8.8 \mathrm{~Hz}$, $\left.\mathrm{H}-2^{\prime}, 6^{\prime}\right), \delta 8.51(\mathrm{H}-2)$, one methoxy group at $\delta 3.78(\mathrm{OMe})$, In addition, the two anomeric proton at $\delta 4.94(J=7.7 \mathrm{~Hz}$, $\left.\mathrm{H}_{\mathrm{glc}}{ }^{-1^{\prime \prime}}\right), \delta 5.12\left(J=7.6 \mathrm{~Hz}, \mathrm{H}_{\mathrm{glc}}-1^{\prime \prime \prime}\right)$ and several other protons at $\delta 3.78-3.30(6 \mathrm{H})$ suggest the presence of a glucosyl moiety. Based on the coupling constant value of the anomeric proton of $\mathbf{1}$, the configuration of the glucosidic linkage was determined to be a $\beta$-linkage. ${ }^{14}$ ) The ${ }^{13} \mathrm{C}$-NMR spectral data of 1 was in good agreement with those of the literature values in tectoridin glucoside. ${ }^{15)}$ All proton and carbon resonances were assigned according to the data obtained from DEPT and HMQC experiments of $1 .{ }^{13} \mathrm{C}-\mathrm{NMR}$ chemical shifts of the sugar carbons in $\mathbf{1}$ were consistent with two glucose units. ${ }^{16)}$ The ${ }^{13} \mathrm{C}$-NMR spectrum of 1 showed the presence of two interglucosidic linkage signals at $\delta 60.2\left(\mathrm{C}_{\mathrm{glc}}-6^{\prime \prime}\right)$ and $\delta 61.0\left(\mathrm{C}_{\mathrm{glc}}-6^{\prime \prime \prime}\right)$, one methoxy group at $\delta 60.8\left(\mathrm{O}-\mathrm{CH}_{3}\right)$, benzene ring signals and glucosyl moiety. In the HMBC spectrum of $1, \delta 4.94\left(J=7.7 \mathrm{~Hz}, \mathrm{H}_{\mathrm{glc}}-1^{\prime \prime}\right)$ was correlated to a $\delta 156.0(\mathrm{C}-7)$ and the $\delta 5.12\left(\mathrm{~d}, J=7.6 \mathrm{~Hz}, \mathrm{H}_{\mathrm{glc}}-1^{\prime \prime \prime}\right)$ was correlated to a $\delta 157.1\left(\mathrm{C}-4^{\prime}\right)$. In addition, the ${ }^{1} \mathrm{H}-{ }^{13} \mathrm{C}$ longrange correlation between the anomeric proton and the benzen ring carbon of 1 suggest that the sites of attachment of sugars to aglycone moiety at C-7 and C-4' position. The position of the glucosyl group of 1 was confirmed by the 2DNOESY spectrum. The 2D-NOESY spectrum of 1 showed correlations between $\mathrm{H}-3^{\prime}, 5^{\prime}\left(\delta\right.$ 7.13) and $\mathrm{H}_{\mathrm{glc}}{ }^{-1 / \prime \prime}(\delta$ 5.12), and between $\mathrm{H}-8\left(\delta\right.$ 6.91) and $\mathrm{H}_{\mathrm{glc}}-1^{\prime \prime}(\delta$ 4.94). Based on these observations, the compound (1) was determined to be a tectoridin-4' $-O-\beta$-D-glucoside, and reported the first isolation from the viola species.

To examine the effect of compound $\mathbf{1}$ on the expression of MMP-1 in primary human skin fibroblasts. The compound (1) did not show cytotoxicity against human skin fibroblast in test dose $(0.1-1 \mu \mathrm{M}, p<0.001)$ as compared to control. Human skin fibroblasts were treated with $0.01-1 \mu \mathrm{M}$ of 1 for $72 \mathrm{~h}$ after UV irradiation and then, the expression levels of MMP-1 was determined in the culture media by Western blot analysis. The decreased MMP-1 protein expression significantly in a dose-dependent manner; by an average of $73.1 \pm 9.3 \% \quad(p<0.05, n=10) \quad$ at $0.01 \mu \mathrm{M}, \quad 60.8 \pm 11.4 \%$ $(p<0.05, n=10)$ at $0.1 \mu \mathrm{M}$, and $58.4 \pm 10.2 \% \quad(p<0.05$, $n=10)$ at $1 \mu \mathrm{M}$, compared with UV-treated cells. Treatment of positive control (all trans retinoic acid), by an average of $69.5 \pm 8.3 \% \quad(p<0.05, \quad n=10) \quad$ at $0.01 \mu \mathrm{M}, \quad 58.4 \pm 9.9 \%$ $(p<0.05, n=10)$ at $0.1 \mu \mathrm{M}$, and $54.3 \pm 8.7 \%(p<0.05, n=10)$ at $1 \mu \mathrm{M}$, compared with UV-treated cells. Compound $\mathbf{1}$ markedly inhibited UV-induced MMP-1 expression to that of
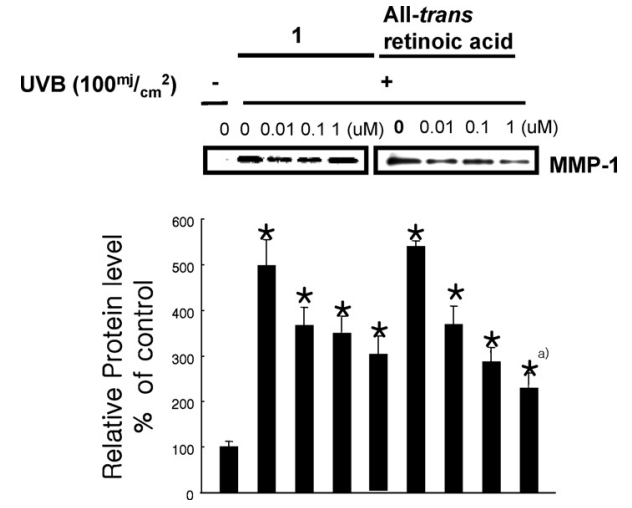

Fig. 2. The Effect of Compound (1) on the Product of MMP-1 Caused by Ultraviolet Irradiation in Cultured Human Skin Fibroblasts

Quiescent primary human foreskin fibroblasts were exposed to UV $100 \mathrm{~mJ} / \mathrm{cm}^{2}$ and collected at indicated time points. Conditioned media of fibroblasts at $72 \mathrm{~h}$ time point following exposure to UV light were collected and Western blotted with anti-MMP-1 antibodies. Data shown are the representative of four independent experiments. Values represent the means \pm S.E. of data from three independent experiments $(* p>0.05$, $n=10$ ). a) Percent of control, significantly different from control: $p<0.05, n=10$.

control (Fig. 2). These results demonstrate that compound 1 reduces the expression of MMP-1 in protein levels. It is well established that the UV irradiation of cultured human skin fibroblasts in vitro or human skin in vivo induces the expression of MMPs, which play important roles in the degradation of extracelluar matrix components during premature skin aging or photoaging. In conclusion, tectoridin- $4^{\prime}-O-\beta$-D-glucoside may be used for the treatment and prevention of skin aging processes by UV irradiation.

Acknowledgement This work was supported by grant Molecular and Cellular Biodiscovery Research Program (M1-0311-00-0152) from the Ministry of Science and Technology.

\section{REFERENCES}

1) Lee Y., "Flora of Korea," Kyohak-sa, Seoul, Korea, 1996, p. 287.

2) Tennstedt D., Comphaut P., Dooms-Goossens A., Lachapelle J. M., Derm. Beruf. Umwelt., 27, 165-169 (1979).

3) Lindholm P., Goransson U., Johansson S., Claeson P., Gullbo J., Larsson R., Bohlin L., Backlund A., Mol. Cancer Ther, 1, 365-369 (2002).

4) Xie C., Veitch N. C., Houghton P., Chem. Pharm. Bull., 51, 1204 1207 (2003).

5) Moon H. I., Chung J. H., Lee J., Zee O., Arch. Pharm. Res., 27, 730733 (2004).

6) Chambers A., Matrisian L., J. Natl. Cancer Inst., 89, 1260-1270 (1997).

7) Gilchrest B., J. Am. Acad. Dermatol., 21, 610-613 (1989).

8) Varan J., Warner R., Gharaee-Kermani M., Phan S., Kang S., Chung J., Wang Z., Datta S., Fisher G., Voorhees J., J. Invest. Dermatol., 114, 480-486 (2000).

9) Fisher G., Wang Z., Datta S., Varani J., Kang S., Voorhees J., N. Engl. J. Med., 337, 1419-1428 (1997).

10) Yook C., Kim I., Hahn D., Nohara T., Chang S., Phytochemistry, 49, 839-843 (1998).

11) Mosmann T., J. Immunol. Methods, 65, 55-63 (1983).

12) Singab A. N., Arch. Pharm. Res., 27, 1023-1028 (2004).

13) Mabry T., Markham K., Thomas M., "The Systematic Identification of Flavonoids," Springer-Verlag, Berlin, 1970, pp. 4, 50.

14) Harborne J., Mabry T., Mabry H., "The Flavonoids," Academic Press, London, New York, 1975, pp. 129, 219.

15) Agrawal P., "Carbon-13 NMR of Flavonoids," Elsevier Sciences Publishing Company INC, New York, 1989, p. 5.

16) Breitmaier E., Voelter W., "Carbon-13 NMR Spectroscopy,” 3rd., VCH Publishers, New York, 1987, p. 227. 